\title{
Reformasi dan keesaan gereja: Makna peristiwa 31 Oktober bagi Gereja Protestan dan Katolik masa kini
}

\author{
Agustinus M. L. Batlajery \\ Fakultas Teologi Universitas Kristen Indonesia Maluku \\ Correspondence: agusmlb@yahoo.com
}

57192211978

Keywords:

Chatolic;

church;

Marthin Lurther;

Protestant;

reformation;

gereja; Katolik;

Protestan;

reformasi

\section{Article History}

Submitted: July 07,2021

Revised: October 02, 2021

Accepted: October 14, 2021

DOI: https://doi.org/

10.30995/kur.v7i2.326

Copyright: @2021, Authors.

License:

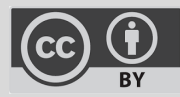

Scan this QR, Read Online

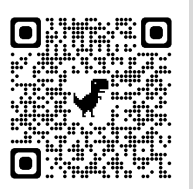

Abstract: It has been well known that the sixteenth-century reformation of the church began on October $31^{\text {st }}, 1517$ when Martin Luther put 95 theses at the gate of Wittenburg church. That is the beginning of reformation but also starting point of church separation and split. While on October 31th 1999 the Lutheran representative and the Catholic leader signed what is called the Joint Declaration on the Doctrine of Justification in which the Protestants and the Catholics show their common understanding of the doctrine of justification. This event could be seen as an indication that unity among two churches is a possibility. So the first October $31^{\text {st }}$ refers to reformation and separation but the second October $31^{\text {st }}$ refers to unity. This article wants to analyze the meaning of these two events for the Protestants and Catholics nowadays. Both churches can learn much from these important events for their present and future relationship. By analyzing the meaning of the valuable historical event we can say that the way to come close to each other and to become one church in the future is open.

Abstrak: Sebagaimana diketahui bersama bahwa reformasi gereja abad ke-16 dimulai pada 31 Oktober 1517, ketika Martin Luther memasang 95 dalil di pintu gerbang gereja di Wittenburg. Itulah permulaan reformasi sekaligus titik awal perpecahan gereja. Sementara pada 31 Oktober 1999 perwakilan dari gereja Lutheran dan pemimpin gereja Katolik menandatangani apa yang disebut Deklarasi Bersama Doktrin tentang Pembenaran, yang di dalamnya gereja Protestan dan Katolik memperlihatkan kesepahaman tentang ajaran pembenaran. Peristiwa tersebut dapat dilihat sebagai petunjuk bahwa kesatuan antara kedua gereja adalah sebuah kemungkinan. Maka 31 Oktober 1517 merupakan tanggal reformasi sekaligus perpecahan, sedangkan 31 Oktober 1999 merupakan tanggal perdamaian atau keesaan. Artikel ini hendak menganalisis makna kedua peristiwa tersebut bagi gereja Protestan dan Katolik masa kini. Kedua gereja dapat belajar banyak dari kedua peristiwa yang penting ini bagi relasi mereka masa kini dan mendatang. Melalui analisis terhadap peristiwa sejarah yang bernilai ini kita dapat mengatakan bahwa jalan kepada kedekatan satu sama lain serta keesaan keduanya telah terbuka.

\section{Pendahuluan}

Di kalangan gereja Protestan dan Katolik, tanggal 31 Oktober 1517 dikenal sebagai hari Reformasi Gereja. Pada tanggal tersebut, Martin Luther menancapkan 95 dalil di pintu gereja istana di Wittenberg sebagai protes kepada kepausan di Roma. Peristiwa tersebut menandai dimulainya 
gerakan reformasi, sekaligus merupakan titik awal perpecahan dalam gereja tradisional, ${ }^{1}$ abad ke-16. Karena itu, 31 Oktober 1517 dipandang juga sebagai tanggal perpecahan gereja.

Selain tanggal 31 Oktober 1517, Gereja Protestan dan Katolik juga mengenal tanggal 31 Oktober 1999. Bila pada tanggal 31 Oktober 1517 terjadi perpecahan gereja, maka pada tanggal 31 Oktober 1999 terjadi perdamaian gereja. Pada tanggal tersebut Gereja Katolik dan Protestan berdamai dengan menandatangani Pernyataan Bersama tentang Doktrin Pembenaran, doktrin yang dipertikaikan dan memisahkan kedua pihak selama berabad-abad. Sejak tahun itu, Katolik dan Protestan makin mendekatkan diri satu sama lain.

Maka, ada dua peristiwa bersejarah penuh makna bagi gereja Katolik dan Protestan yakni 31 Oktober 1517 dan 31 Oktober 1999. Artikel ini akan membahas makna kedua peristiwa tersebut bagi relasi Katolik dan Protestan ke depan. Diawali dengan membahas peristiwa 31 Oktober 1517, dilanjutkan dengan peristiwa 31 Oktober 1999, kemudian sedikit tentang keesaan gereja, lalu berakhir dengan makna peristiwa tersebut bagi kedua gereja ke depan sebelum menarik kesimpulan. Dalam kaitan itu, kesadaran seperti apa yang perlu ada dan bentuk-bentuk kerjasama macam apa sekarang dan ke depan perlu dipikirkan pula.

\section{Metode Penelitian}

Artikel ini berupaya menangkap makna peristiwa 31 Oktober 1517 dan 31 Oktober 1999 bagi Gereja Protestan dan Katolik ke depan. Metode yang digunakan dalam pembahasan ini adalah metode kualitatif dengan pendekatan studi kepustakaan. Analisis data menggunakan analisis sejarah dogmatis, yakni dengan memanfaatkan sumber-sumber sejarah gereja dan ajaran gereja untuk merumuskan sebuah konsep bergereja di masa kini dan masa depan. Studi kepustakaan terhadap sumber-sumber historis-dogmatis tersebut diawali dengan meneliti peristiwa 31 Oktober 1517 yang dilihat sebagai reformasi sekaligus perpecahan gereja, dilanjutkan dengan 31 Oktober 1999 yang dilihat sebagai upaya ke arah keesaan gereja. Kemudian mengulas sedikit tentang keesaan gereja lalu diakhiri dengan makna kedua peristiwa tersebut bagi Gereja Katolik dan Protestan ke depan. Pokok pikiran yang hendak dikembangkan oleh tulisan ini adalah terbuka kemungkinan bagi Gereja Katolik dan Protestan untuk bersatu dan mengesa di waktu-waktu mendatang.

\section{Pembahasan}

\section{Peristiwa 31 Oktober 1517: Pemasangan 95 Dalil Martin Luther}

Sejarah mencatat bahwa Martin Luther memasang 95 dalil di pintu sebuah gereja di Wittenberg pada tanggal 31 Oktober 1517. Ke-95 dalil tersebut berisi kritik-kritiknya terhadap ajaran dan praktik gereja Katolik waktu itu yang menurutnya bertentangan dengan kesaksian Alkitab. Peristiwa itulah yang merupakan awal mula Gereja Reformasi di Eropa yang kemudian menyebar ke seluruh dunia dan melahirkan Protestantisme. Oleh karena itu, dapat dikatakan bahwa bila Martin Luther tidak melakukan tindakan ini maka tidak akan ada Protestantisme di dunia. Bila Gereja Katolik tidak menolak protes-protesnya maka tidak akan ada Gereja Protestan atau Gereja Reformasi di dunia. Dengan demikian, peristiwa 31 Oktober 1517 di Wittenberg merupakan momentum sejarah yang sangat menentukan bagi lahirnya Protestantisme.

Dalam rangka memperingati 500 tahun reformasi gereja empat tahun lalu, cukup banyak kajian telah dibuat orang. Mereka mencoba mengungkapkan makna reformasi gereja yang dilakukan Martin Luther dari berbagai sudut pandang. Buku berjudul "Musa Jerman" yang disunting oleh A. Eddy Krisyanto dan diterbitkan oleh BPK Gunung Mulia patut disebutkan. Buku

\footnotetext{
${ }^{1}$ Para sejarawan reformasi membedakan gereja pada masa sebelum Konsili Trente dan sesudahnya. Gereja sebelum Konsili Trente disebut Gereja Tradisional (Traditional Church), sedangkan gereja sesudah Konsili Trente disebut Gereja Roma Katolik (RK) sebagaimana yang kita kenal sekarang. Konsili Trente-lah yang menentukan adanya Gereja Roma Katolik. Bila nama Katolik dipakai itu hanya untuk memudahkan pengertian saja.
} 
tersebut memuat berbagai telaah tentang peristiwa besar ke-16 itu, mulai dari latar belakang, kehidupan personalitas Martin Luther sampai gagasan-gagasan teologinya yang cemerlang. ${ }^{2}$

Oleh karena itu, dalam pembahasan ini latar belakang timbulnya reformasi tidak lagi disinggung. Tentang hal itu, banyak buku sejarah gereja yang tersedia dalam bahasa Indonesia telah membahasnya. ${ }^{3}$ Cukuplah di sini diberi perhatian pada apa yang saya sebut 'key event' yang menjadi pintu masuk dalam memahami keseluruhan kisah reformasi yakni 95 Dalil yang dipakukan Luther di pintu gedung gereja istana di Wittenberg pada 31 Oktober 1517. Dalam hal ini, saya mengacu kepada buku kecil dari Van den End yang diterbitkan tahun 2017. ${ }^{4}$ Dalam buku tersebut, di samping menguraikan latar belakang sejarah munculnya 95 dalil, Van den End juga mengemukakan analisisnya terhadap makna dalil-dalil tersebut. Berikut beberapa hal dari uraiannya yang dapat dicatat.

\section{Akar Masalah}

Akar masalahnya adalah pada ajaran dan praktik penghapusan hukuman berkaitan dengan pengakuan dosa yang memang telah lama dipermasalahkan. Dalam ajaran gereja tradisional waktu itu, pengakuan dosa merupakan akta gereja yang penting bahkan menjadi salah satu sakramen. Praktiknya mula-mula dilakukan terhadap dan di antara sesama warga jemaat saja secara sukarela. Tetapi kemudian kebiasaan ini dilembagakan dalam bentuk keputusan Konsili Lateran IV tahun 1215. Konsili menetapkan bahwa semua warga jemaat wajib melakukan pengakuan dosa paling tidak satu kali setahun di hadapan imam. Juga diputuskan bahwa hanya imam saja yang berwewenang mengucapkan rumus pengampunan dan menetapkan hukuman apa yang harus mereka tanggung akibat perbuatan dosanya itu. Bentuk dosa dan jenis hukumannya sudah tercantum dalam buku daftar dosa. Imam tinggal mencocokkan saja perbuatan dosa dengan hukumannya sebagaimana tercantum dalam daftar tersebut. ${ }^{5}$

Tatkala imam mengucapkan rumus pengampunan, ia mewajibkan orang melakukan perbuatan tertentu untuk membuktikan kesungguhan penyesalannya. Maka, kendati pengampunan sudah dinyatakan, hukuman tetap dijalani. Pernyataan pengampunan tidak membebaskannya dari hukuman yang harus ia jalani, bahkan hukuman itu bukan saja dijalani di dunia melainkan akan dijalani juga sesudah mati di dalam api penyucian. ${ }^{6}$ Dengan cara demikian, pikiran dari setiap warga gereja tradisional waktu itu adalah bagaimana agar ia bisa bebas dari hukuman. Sebab meskipun mereka sudah diampuni, namun hukuman tetap harus dijalani.

\section{Cara Menggantikan Pelaksanaan Hukuman}

Pertanyaan tentang bagaimana supaya seseorang, sesudah mengaku dosa dan menerima pengampunan, tidak harus menjalani hukuman lagi, terus dicari jawabannya. Cara apakah yang dapat ditempuh agar bisa bebas dari menjalani hukuman? Apakah bisa dengan membayar sejumlah uang maka hukuman terlunasi? Rupa-rupanya kemungkinan menempuh cara ini mulai diperkembangkan. Bertepatan waktu itu, pihak gereja memerlukan banyak uang untuk membelanjai berbagai keperluan, antara lain pembangunan gedung gereja Santo Petrus yang besar dan megah itu. Cara ini dipandang bisa menjadi sumber pendapatan. Gereja lalu mengembangkan sistem membayar sejumlah uang bila ingin bebas dari penghukuman. Maka, membayar sejumlah uang atau denda menjadi cara menjalani hukuman. Dengan begitu maka hukuman dalam bentuk melakukan perbuatan tertentu ditiadakan. ${ }^{7}$ Malahan hukuman berupa menjalani api penyucian pun dapat dihapuskan dengan membayar sejumlah uang. Jadi mereka yang hidupnya dipenuhi

\footnotetext{
${ }^{2}$ Eddy Krisyanto, ed., Musa Jerman (Jakarta: BPK Gunung Mulia, 2017), 9-57, 129-148, 151-166.

3 Th. Van den End, Harta Dalam Bejana (Jakarta: BPK Gunung Mulia, 1982); Jan Sihar Aritonang, Garis Besar Sejarah Reformasi (Bandung: Jurnal Info Media, 2007); Jan S. Aritonang, Berbagai Aliran Di Dalam Dan Di Sekitar Gereja (Jakarta: BPK Gunung Mulia, 2016); Tony Lane, Runtul Pijar (Jakarta: BPK Gunung Mulia, 1990).

${ }^{4}$ Th. van den End, 95 Dalil Martin Luther (Jakarta: BPK Gunung Mulia, 2017), 23-61.

${ }^{5}$ Ibid., 2.

${ }^{6}$ Ibid., 3.

7 Ibid., 2-3.
} 
ketakutan akan maut dan neraka sekarang boleh merasa lega. Bahkan membayar sejumlah uang atas nama orang lain agar orang itu bebas dari api siksaan juga dimungkinkan. Ajaran dan praktik semacam ini berlangsung terus sampai abad ke-16.

\section{Titik Kulminasi}

"Pada awal abad ke-16, praktik mengejar penghapusan dosa sudah benar-benar melampaui batas yang wajar dan sedang merongrong sakramen pengakuan dosa sendiri. Pada zaman itu ditawarkan kesempatan tak terhitung untuk memperolehnya. Di pihak lain, permintaannya juga besar sekali", demikian Van den End. ${ }^{8}$ Masalah teologis mendasar yang muncul adalah bahwa kesempatan menggantikan perbuatan penyesalan yang nyata dengan membayar sejumlah uang, telah melonggarkan ikatan antara sakramen pengakuan dosa pada umumnya dan penyesalan karena dosa pada khususnya. Malahan ikatan itu semakin longgar oleh kemungkinan menebus hukuman orang lain. Pengakuan dosa sebagai sebuah sakramen yang pada gilirannya menghasilkan penyesalan dan pertobatan oleh pekerjaan Roh Kudus, menjadi hilang maknanya.

Pada sekitar tahun 1510, Paus Yulius II yang menduduki takhta kepausan sejak 1506-1513, ${ }^{9}$ merencanakan pembangunan sebuah gereja induk bagi orang Katolik seluruh dunia di atas makam Paus yang pertama yakni Rasul Petrus di Roma. Direncanakanlah pembangunan gedung gereja itu dengan biaya mahal. Maka Paus menggunakan suasana antusiasme warga kala itu sebagai kesempatan emas. Ia lalu memutuskan menggunakan cara itu untuk mendanai pembangunan Gereja St. Petrus yang baru. Cara memperoleh uang tambahan guna pelaksanaan pembangunan ditempuh dengan menjual indulgensia (surat penghapusan hukuman/siksa). Paus menyatakan bahwa yang menyumbangkan uang untuk pembangunan gereja itu akan menerima penghapusan hukuman yang telah dikenakan kepadanya oleh gereja, termasuk hukuman yang akan diderita dalam api penyucian. Kiat tersebut berlaku untuk seluruh Eropa Barat dan Tengah. ${ }^{10}$ la lalu mengangkat para komisaris wilayah untuk mengelola proyek itu di wilayahnya masingmasing. Albrecht, sebagai Uskup Agung Magdeburg sekaligus merangkap uskup Halberstraat dan Mainz adalah salah satunya. Albrecht kemudian mengangkat sejumlah agen sebagai kaki tangannya untuk mempropagandakan surat-surat penghapusan hukuman kepada rakyat yang berkumpul dalam gedung-gedung gereja. Salah satu agennya yang terkenal sangat fasih adalah Johan Tetzel, seorang dari Ordo Dominikan. Dengan propagandanya yang hebat, Tetzel berhasil mengumpulkan banyak uang.

Hambatan yang dialami Luther dalam pelayanannya sebagai imam adalah bahwa ketika ia melaksanakan sakramen pengakuan dosa, orang-orang yang ia layani tidak mau lagi menjalankan ketentuan hukuman dengan alasan mereka sudah memiliki surat penghapusan hukuman di tangannya. Mereka tidak mau menyesal dan bertobat gara-gara sudah memegang surat tersebut. Terhadap kenyataan ini Luther sudah mewacanakan pendapatnya melawan fenomena itu sejak tahun 1513. Bermula di ruang kelas kepada para mahasiswa, kemudian di mimbar gereja melalui khotbah. Dengan cara itu ia berhasil membuat heboh masyarakat, kendati kepausan tetap pada praktiknya. Akhirnya usahanya mengeritik gereja memuncak pada ditempelkannya 95 dalil di depan pintu Gereja Wittenberg pada tanggal 31 Oktober 1517. la memilih tanggal 31 Oktober, sehari sebelum 1 November sebab tiap-tiap tahun pada tanggal 1 November, dalam gereja di istana dibawakan khotbah tentang penghapusan hukuman yang dapat diperoleh dengan bantuan relikui-relikui yang telah dikumpulkan oleh Raja Friedrich. ${ }^{11}$ la lalu mengirim surat kepada Uskup Agung Albrecht dengan melampirkan 95 dalil tersebut. Maksud utamanya adalah agar kepausan mengubah teologi, ajaran dan praktiknya. Lagi pula agar para rohaniwan dan teolog mendiskusikan dalil-dalil tersebut, Adalah jauh dari pikirannya untuk menciptakan sebuah gereja baru. Ternyata, 95 dalil tersebut menggemparkan gereja Katolik di Eropa dan menandai awal dimulainya reformasi gereja yang pada gilirannya melahirkan Gereja Protestan.

\footnotetext{
${ }^{8}$ Ibid., 4.

${ }^{9}$ John Juliua Norwich, The Popes A History (London: Chatto \& Windus, 2011), 241.

${ }^{10}$ End, 95 Dalil Martin Luther, 7.

${ }^{11}$ Ibid., 9.
} 


\section{Tinjauan terhadap 95 Dalil Martin Luther}

Dalam bukunya yang disebutkan di atas, Van den End mengemukakan tinjauan analisisnya terhadap 95 dalil Martin Luther. ${ }^{12}$ Ada satu hal menarik yang akan diberi perhatian khusus oleh tulisan ini yakni arti ke-95 dalil untuk relasi Gereja Reformasi dan Gereja Katolik. Menurutnya, Luther didakwa karena sudah terkenal sebagai penyesat dan dalil-dalilnya ditolak oleh dua universitas terkenal di Koln (Jerman) dan di Leuven (sekarang Belgia). Lagi pula Paus mengeluarkan Bulla Eksurge Domine pada tanggal 15 Juni 1520 yang menyebut dan mengutuk empat puluh satu ucapan Luther yang sebagian besar menyangkut sakramen pengakuan dosa dan pemberian surat penghapusan hukuman. ${ }^{13}$

Semua ini telah menimbulkan diskusi yang hebat di mana-mana bahkan sejak tahun 1517 yang mungkin tak akan pernah selesai tentang pokok-pokok tersebut sampai kedatangan kembali Yesus Kristus di atas awan-awan. Namun selanjutnya ia berkata:

Kendali demikian, ada alasan untuk bersyukur. Dewasa ini kedua belah pihak tidak lagi saling membunuh karena perbedaan pendapatnya. Mereka juga tidak lagi menyangkal status lawan sebagai orang Kristen. Sebagaimana dalam tahun 1960-an sudah ditulis oleh Dr.H. Emburu, SVD dalam text booknya Gereja Sepanjang Masa, "warga Katolik tidak percaya bahwa yang bukan Katolik akan dibuang dalam api neraka". Kita saling mengakui sebagai sebagian umat Allah yang sedang berziarah ke kota Yerusalem yang baru. ${ }^{14}$

Kita dapat mengerti bahwa suasana abad ke-16 memang sangat panas dan menegangkan. Otori-tas gereja merasa terancam, kutuk-mengutuk tak dapat dihindari. Pemimpin gereja cenderung mempertahankan posisinya dan mau berhadap-hadapan dengan siapa saja yang mengeritiknya. Bahkan bila perlu, para lawan gereja dibinasakan. Sikap semacam ini masih berlangsung sampai Konsili Trente (1545-1563) dan Konsili Vatikan I (1869-1870). Akan tetapi, dalam perjalanan sejarah selama lima abad kemudian telah terjadi perubahan besar dalam sikap, pandangan dan hubungan Katolik-Protestan terutama pada Konsili Vatikan II (1962-1965). Kita mencatat beberapa perubahan berikut ini. Bila pada konsili Trente dan Vatikan I orang-orang Protestan disebut sebagai "orang yang tersesat", maka pada Konsili Vatikan II orang-orang Protestan disapa sebagai "Saudara". ${ }^{15}$ Tepatnya "saudara-saudara yang terpisah, namun satu dengan gereja Katolik dalam iman kepada Kristus". ${ }^{16}$

Selanjutnya, bila pada Konsili Trente dan Vatikan I sikap terhadap Protestantisme sangat tertutup, maka pada Konsili Vatikan II terjadi perubahan yang luar biasa. Protestantisme dan bahkan agama-agama besar dunia lainnya dipandang sebagai "yang juga memancarkan sinarsinar terang". ${ }^{17}$ Dalam dekrit yang pertama dari Konsili tersebut, dengan singkat dan amat hatihati dikatakan: "Gereja Katolik tidak menolak apa-apa dari hal-hal yang benar dan suci pada agama-agama ini. Gereja memandang dengan hormat cara bertindak dan cara hidup serta perintah-perintah dan ajaran-ajaran yang, kendati kerap kali berlainan dengan yang dipegang dan dibeberkan oleh gereja, kerap kali mencerminkan sinar kebenaran yang menerangi setiap orang". ${ }^{18}$

Perkembangan-perkembangan di atas tentu bermanfaat bagi perenungan dan refleksi kedua gereja. Banyak makna dapat dipetik dari padanya. Hal itu akan dikemukakan pada bagian akhir artikel ini. Baiklah sekarang kita meninjau peristiwa 31 Oktober 1999.

\section{Peristiwa 31 Oktober 1999: Pernyataan Bersama Katolik dan Protestan}

Sebagaimana kita ketahui, ajaran tentang pembenaran oleh iman atau keselamatan oleh anugerah Allah saja, telah merupakan inti pokok yang membedakan serta memisahkan gereja Protestan

\footnotetext{
12 Ibid., 47-61.

${ }^{13}$ Ibid., 57.

${ }^{14}$ Ibid., 59-60.

${ }^{15}$ Norman P. Tanner, Konsili-Konsili Gereja Sebuah Sejarah Singkat (Yogyakarta: Kanisius, 2003), 128.

${ }^{16}$ Andar Ismail, Selamat Membarui (Jakarta: BPK Gunung Mulia, 2017), 126.

${ }^{17}$ B.F. Drewes and Julianus Mojau, Apa Itu Teologi? (Jakarta: BPK Gunung Mulia, 2003), 60.

${ }^{18}$ Tanner, Konsili-Konsili Gereja Sebuah Sejarah Singkat, 130.
} 
dan Katolik sejak reformasi, sampai lima ratus tahun sesudahnya. Perbedaan itu ditegaskan dalam tiga semboyan reformasi yakni Sola Gratia (hanya oleh anugerah), Sola Fide (hanya oleh iman), dan Sola Scriptura (hanya oleh Alkitab). Perbedaan itu pun secara sadar telah diinternalisasikan oleh kedua belah piihak kepada masing-masing komunitasnya, maupun di seminariseminari dan sekolah tinggi teologi miliknya. Perbedaan ini pula telah menjauhkan kedua gereja selama berabad-abad. Namun, pada abad ke-20 telah terjadi perkembangan yang luar biasa. Selain perubahan cara pandang yang cukup mencolok pada konsili Vatikan II, peristiwa bersejarah lainnya yang berdampak besar bagi relasi keduanya, yakni penadatanganan pernyataan bersama ajaran tentang pembenaran pada tanggal 31 Oktober 1999.

Deklarasi Bersama Tentang Doktrin Pembenaran (Joint Declaration on the Doctrine of Justification, JDDJ) adalah sebuah dokumen bersejarah dalam kekristenan, khususnya mengenai relasi Katolik dan Protestan di seluruh dunia. Di dalam dokumen tersebut kedua gereja sepakat tentang Ajaran Pembenaran yang telah berabad-abad memisahkan mereka. Hal itu terjadi setelah keduanya melakukan perenungan terhadap Alkitab dan dialog-dialog terbuka yang hangat. Latar belakang sejarah, isi serta analisis terhadap dokumen tersebut telah dipaparkan dan dilakukan dengan baik oleh Ramli S.N. Harahap dalam buku yang dipublikasi pada tahun $2015 .{ }^{19}$

Menurutnya, sebelum Deklarasi ini tercapai, kedua belah pihak telah memulai pembicaraan tentang Deklarasi Bersama ini. Di satu sisi, sejumlah teolog Gereja Katolik Roma telah berusaha membahas topik pembenaran ini sejak tahun 1960-an yang dipublikasikan melalui disertasi. Misalnya disertasi Otto H. Pesch, yang membahas 'memperbaiki perbedaan' di antara Luther dan Thomas Aquinas tentang dokrin pembenaran. Demikian juga disertasi Prof. Joseph Ratzinger (Paus Benedictus XVI) tahun 1960-an di Bonn yang menginvestigasi Konfesi Augsburg (25 Juni 1530) dan respons apologetik Katolik terhadap Konfesi Augsburg tersebut. Di sisi lain, teolog Lutheran juga melakukan pembahasan atas aspek-aspek dalam Deklarasi Bersama tersebut sejak tahun 1960-an, misalnya studi atas pemikiran Thomas Aquinas oleh Hans Vorster dan Ulrich Kuhn. ${ }^{20}$

Selain itu, dilakukan pula usaha-usaha dialog antara kedua pihak, demikian Harahap. la mencatat bahwa usaha dialog Protestan-Katolik ini besar kaitannya dengan ulasan Hans Küng dalam disertasi doktoralnya yang berjudul Justification: The Doctrine of Karl Barth and a Catholic Reflection. Dalam disertasinya Küng mencoba membuka peluang dialog antara Protestan-Katolik mengenai doktrin pembenaran oleh iman. Küng memaparkan hal-hal yang bisa membuka peluang untuk dialog dengan mengatakan bahwa apa yang diputuskan di dalam Konsili Trente tentang ajaran pembenaran iman Reformasi merupakan keputusan yang salah, karena didasarkan atas kesalahpahaman dan kekurang-mengertian tentang ajaran pembenaran iman itu sendiri. Padahal, di dalam deklarasi Lutheran-Gereja Katolik Malta Report disebutkan: "Lutheran dan Gereja Katolik Roma setuju bahwa Injil adalah dasar atas kebebasan Kristen. Kebebasan ini digambarkan di dalam Perjanjian Baru (PB) seperti bebas dari dosa, bebas dari kuasa Hukum Taurat, bebas dari kematian, dan kebebasan melayani Allah dan sesama manusia. ${ }^{21}$

Harus diakui pula, lanjut Harahap, bahwa pemrakarsa dialog Lutheran-Katolik ini adalah dari kalangan Lutheran. Pada 1972 sebuah pernyataan dipublikasikan oleh Komite Studi Bersama yang diundang oleh Federasi Gereja-gereja Lutheran Se-Dunia (The Lutheran World Federation [LWF]) dan Sekretariat Promosi Kesatuan Gereja Kristen (The Secretariate for Promoting Christian Unity [SPCU]). Inilah yang dikenal dengan Laporan Malta (Malta Report), yang draft akhir dokumen ini selesai dikerjakan di San Anton, Malta, 1971 dan dipublikasikan atas nama 'The Gospel and the Church'. Ulasan tentang pembenaran sangat singkat sekali, dan mengatakan, "Today... a far-reaching consensus is developing in the interpretation of justification".

\footnotetext{
${ }^{19}$ Ramli SN Harahap, Deklarasi Bersama Tentang Ajaran Pembenaran Oleh Iman (Yogyakarta: Kanisius, 2015).

${ }^{20}$ Ibid., 38.

${ }^{21}$ Ibid., 39.
} 
Setelah Laporan Malta 1971, dialog internasional Lutheran - Katolik mulai produktif dilakukan dalam fase kedua. Peringatan 450 tahun Konfesi Augsburg 1980 di bawah tema 'Seluruhnya di bawah Satu Kristus' menghasilkan sebuah deklarasi yang bunyinya sebagai berikut:

A broad consensus emerges in the doctrine of justification, which was decisively important for Reformation (CA IV): it is solely by grace and by faith in Christ's saving work and not because of any merit in us... Together we testify that the salvation accomplished by Christ in his death and resurrection is bestowed on and effectively appropriated by humanity in the proclaim of the gospel in the holy sacrament through the Holy Spirit. ${ }^{22}$

Apa yang telah diuraikan di atas merupakan cikal bakal lahirnya Deklarasi Bersama tersebut. Selanjutnya bila diamati, demikian Harahap, lahirnya Deklarasi Bersama ini sangat dipengaruhi oleh kunjungan Paus Yohanes Paulus II ke Jerman pada 17 November 1980. la mengadakan pertemuan dengan Gereja Lutheran dan Reformed (Calvinis) di Mainz. Pada saat itu, Landesbischof Eduard Lohse, Ketua Dewan Gereja Evangelis Jerman [The Council of the Evangelical Church in Germany (EKD) menyampaikan kebutuhan kerja sama yang lebih baik dengan Gereja Katolik Roma pada Ibadah Minggu, Perjamuan Kudus, dan perkawinan campur. ${ }^{23}$

Tahun 1995, sebuah draft telah dibagikan pada Gereja-gereja untuk dibahas dan dikomentari. Dan pada 1997, Deklarasi Bersama ini dipublikasikan yang diikuti dengan berbagai diskusi. LWF telah meminta anggota-anggotanya untuk memberi masukan dan jawaban pada Mei 1998 apakah anggota-anggota Gereja LWF menerima kesimpulan Deklarasi Bersama tersebut. Atas dasar masukan-masukan dari anggota-anggotanya, maka LWF mengelaborasi dokumen di Würzburg (FRG), Juni 1996. Kemudian dikirimkan ke Gereja-gereja untuk lebih dipertajam dan dikoreksi agar lebih matang. Januari 1997, draft akhir telah dikirimkan ke Gereja-gereja dengan harapan agar draft akhir ini dibahas dalam setiap sinode Gereja masing-masing dan hasil akhir dari Gereja-gereja akan dikirimkan kembali ke LWF pada akhir Pebruari 1997.24

Singkat cerita, pada akhirnya pada tanggal 31 Oktober 1999 perwakilan dari Gereja Lutheran dan Utusan dari Vatikan menandatangani naskah Deklarasi Bersama Tentang Ajaran Pembenaran Oleh Iman (JDDJ) di Augsburg, Jerman. Deklarasi Bersama tersebut terdiri dari 44 Pasal. ${ }^{25}$ Di sini hanya dikutip dua pasalnya saja yakni pasal 14 dan 15 mengingat ruang dan waktu yang terbatas bagi kita:

Pasal 14 berbunyi:

Gereja-gereja Lutheran dan Gereja Katolik Roma senantiasa dengar-dengaran pada kabar gembira yang diberitakan dalam Kitab Suci. Kesediaan mendengar seperti itu, bersama dengan percakapan teologis pada tahun-tahun belakangan ini, memungkinkan adanya pemahaman bersama akan ajaran pembenaran. Pemahaman ini mencakup kesepakatan dalam kebenarankebenaran dasariah; kalaupun ada penguraian lanjutan yang berbeda dalam pernyataan-pernyataan yang lebih terperinci, semuanya itu dapat dipersatukan dengan kebenaran dasariah ini. ${ }^{\mathbf{2 6}}$

Pasal 15 berbunyi:

Kami bersama-sama mengakui bahwa pembenaran adalah karya Allah Tritunggal. Allah Bapa mengutus anak-Nya ke dunia ini untuk menyelamatkan orang berdosa. Dasar dan syarat pembenaran adalah inkarnasi, kematian, dan kebangkitan Kristus. Oleh karena itu, pembenaran berarti bahwa Kristus sendiri adalah kebenaran kita; dan kita mengambil bagian dengan kebenaran ini melalui Roh Kudus sesuai dengan kehendak Bapa. Kami bersama-sama mengakui: hanya oleh anugerah, dalam iman akan karya penyelamatan Kristus dan bukan karena perbuatan kita, kita diterima oleh Allah dan diterima oleh Roh Kudus, yang memperbarui hati kita serta memampukan dan memanggil kita untuk perbuatan-perbuatan baik." ${ }^{27}$

\footnotetext{
22 Ibid.

${ }^{23}$ Ibid., 44.

24 Ibid., 46.

${ }^{25}$ Ibid., 66-70.

${ }^{26}$ Ibid., 65.

${ }^{27}$ Ibid., 66.
} 
Pasal 14 merupakan ungkapan kesaksian bahwa pernyataan ini lahir dari perjalanan panjang mempelajari Alkitab secara bersama. Kedua pihak meninggalkan ego masing-masing dan menundukkan diri di bawah kuasa Alkitab dalam tuntunan Roh Kudus. Sedangkan pasal 15 merupakan inti dari pernyataan bersama tersebut. Dua-duanya mengaku bahwa manusia diselamatkan hanya oleh anugerah dalam iman akan karya penebusan Kristus, bukan karena perbuatan baik atau amal. Peristiwa penting dan bersejarah ini tentu saja sangat bermakna bagi relasi Katolik dan Protestan kini dan ke depan.

\section{Keesaan Gereja}

Sebelum menarik makna dari peristiwa 31 Oktober yang telah diuraikan di atas bagi kehidupan gereja masa kini, maka baiklah disinggung sedikit tentang keesaan gereja sebagai panggilan bersama seluruh gereja. Tidak akan disinggung aspek historisnya, juga tahapan-tahapan perkembangannya. Begitu pula tentang lembaga-lembaga oikumenis serta apa yang telah dicapai. ${ }^{28}$ Yang ingin dikemukakan di sini secara singkat adalah menegaskan bahwa panggilan oikumenis seluruh gereja adalah mengusahakan keesaan sebagaimana doa Yesus dalam Injil Yohanes. Baik Gereja Orthodox, Gereja Katolik maupun Gereja Protestan beserta semua turunannya mempunyai panggilan yang satu dan sama yakni untuk mengusahakan dan mewujudkan keesaan gereja.

Dalam kaitan itu, panggilan bersama gereja-gereja di Indonesia sebagaimana tertuang dalam Dokumen Keesaan Gereja (DKG 2019-2024) adalah sebagai berikut:

Menampakkan keesaan gereja-gereja, seperti keesaan tubuh Kristus dengan rupa-rupa karunia, tetapi satu Roh yang selalu membarui (band. Rm.12:1-8; 1Kor.12:4); panggilan gereja mengharuskan gereja hidup berpadanan dengan Injil, dan mengharuskan gereja-gereja sebagai tubuh Kristus, sehati sepikir berjuang untuk iman yang ditimbulkan oleh berita Injil, dan mengharuskan gereja-gereja untuk saling memahami, memperhatikan, dan melayani demi kepentingan bersama (band. Flp.1:27; 2:4; 1 Kor.12:27). Itulah tugas keesaan yaitu tugas membarui, membangun dan mempersatukan gereja." 29

Selanjutnya, tentang panggilan mempersatukan gereja dikatakan bahwa panggilan mempersatukan gereja berarti mewujudkan hakikat keesaan gereja yang berdasar pada keesaan Allah Trinitas, Bapa, Anak, dan Roh Kudus, yakni suatu keesaan dalam ikatan kerja sama, dalam bentuk-bentuk kelembagaan yang secara efisien mendukung pelaksanaan panggilan bersama gereja-gereja. Keesaan Gereja adalah keesaan dalam kepelbagaian karunia yang masing-masing gereja terima dan jalankan dalam sejarahnya. Kepelbagaian tidak dihilangkan, tidak juga menjadi penghalang, tetapi mendukung kebersamaan menjalankan panggilan gereja. ${ }^{30}$

Dokumen keesaan gereja memang berbicara tentang panggilan keesaan di kalangan gerejagereja yang tergabung dalam Persekutuan Gereja-Gereja di Indonesia (PGI). Namun sesungguhnya, panggilan keesaan semacam itu adalah panggilan semua gereja. Karena itu baik Katolik maupun Protestan, bahkan Orthodox, semuanya mempunyai panggilan yang sama. Kendati demikian, panggilan keesaan ini diarahkan khusus kepada Gereja Katolik dan Protestan, berhubung dengan pembahasan yang panjang tentang peristiwa 31 Oktober yang telah dilakukan. Oleh karena itu, makna peristiwa 31 Oktober mau diarahkan pada upaya keesaan antara Katolik dan Protestan. Dengan kata lain, kalau Reformasi Gereja 31 Oktober 1517 menghasilkan perpecahan gereja, maka peristiwa 31 Oktober 1999 menghasilkan keesaan.

\section{Makna peristiwa 31 Oktober bagi Gereja masa kini}

Mengawali renungan singkatnya yang berjudul "Tanggal 31 Oktober", Andar Ismail berkata:

Belum banyak orang tahu bahwa tanggal 31 Oktober bukan hanya merupakan tanggal perpecahan, melainkan juga tanggal perdamaian kembali antara Gereja Katolik dan Gereja Protestan. Pada tanggal 31 Oktober 1999 bertempat di Augsburg, Jerman, Gereja Katolik dan Gereja Pro-

\footnotetext{
${ }^{28}$ Christiaan de Jonge, Menuju Keesaan Gereja (Jakarta: BPK Gunung Mulia, 1990).

${ }^{29}$ PGI, Dokumen Keesaan Gereja 2019-2024 (Jakarta: BPK Gunung Mulia, 2020), 10.

${ }^{30}$ Ibid., 17.
} 
testan menandatangani kesepakatan mengenai sebuah ajaran yang paling dipertikaikan dan yang menjadi penyebab perpecahan gereja sejak tahun 1517. Pokok ajaran itu adalah doktrin tentang pembenaran. ${ }^{31}$

Pernyataan Andar Ismail ini menyadarkan kita bahwa di masa depan, jalan terbuka bagi keesaan antara Gereja Katolik dan Protestan bukan sesuatu yang mustahil. Dan untuk sampai ke sana, kedua gereja perlu menarik makna dari peristiwa 31 Oktober 1517 dan 31 Oktober 1999. Berikut ini beberapa catatan penting untuk disadari dan dipikirkan bersama.

\section{Institusi Gereja Bisa Salah}

Gereja bisa menyimpang dari ajarannya dalam praktik bergereja. Ajaran bisa lain, praktik bisa lain. Karena itu kalau kita mau membaharui gereja, amati praktiknya. Praktik merupakan pintu masuk untuk melakukan pembaharuan dalam gereja. Hal ini jelas bila kita memperhatikan struktur dari ke-95 dalil Martin Luther. Luther tidak mulai dengan ajaran tentang keselamatan oleh anugerah (sola gratia). la justeru mulai dengan ajakan untuk bertobat dari praktik-praktik keliru yang pada intinya menyimpang jauh dari ajaran. Dalil pertama berbunyi: "Tatkala Tuhan dan Guru kita Yesus Kristus berkata, "Bertobatlah" dst., maka la menghendaki supaya seluruh kehidupan orang percaya merupakan pertobatan. ${ }^{\prime 23}$ Pertobatan itu dijelaskan selanjutnya dalam dalil kedua sampai keempat demikian:

Pertobatan ini tidak boleh dianggap menyangkut pertobatan dalam rangka sakramen (yaitu pertobatan dalam pengakuan dan penyilihan yang dilaksanakan oleh palayanan para imam). Kendati demikian, maksudnya bukan juga pertobatan batiniah semata. Yang batiniah bahkan tiada artinya jika tidak menghasilkan pelbagai perbuatan lahiriah yang mematikan daging. Oleh sebab itu, hukuman tetap ada selama kebencian terhadap dirinya ada (yaitu pertobatan batiniah yang sungguh-sungguh), artinya, sampai orang masuk ke dalam kerajaan surga. ${ }^{33}$

\section{Hubungan dengan Gereja Roma Katolik: Upaya ke arah Gereja Esa}

Kendati perbedaan teologi antara Gereja Roma Katolik dengan Gereja Protestan masih terlihat, namun patut disyukuri bahwa rasa permusuhan di antara keduanya sudah lenyap. Keduanya telah saling mengakui sebagai umat Allah "yang sedang berziarah menuju Yerusalem yang baru", meminjam kata-kata Van den End. Konsili Vatikan II yang dilaksanakan tahun 1962-1965 telah membawa perubahan sikap Gereja Katolik terhadap Gereja Protestan sebagai bukan lagi "orang yang tersesat", melainkan sebagai "saudara-saudara yang terpisah, namun satu dengan Gereja Katolik dalam iman kepada Kristus". Konsili juga menyerukan agar umat Katolik bekerja sama dengan "saudara-saudara kita itu", ${ }^{34}$ maksudnya umat Protestan.

Dalam hal teologi dan ajaran, telah pula terjadi perkembangan yang mengarah kepada perubahan dan pengakuan yang sangat signifikan. Pada tanggal 31 Oktober 1999, 21 tahun yang lalu, bertempat di Augsburg, Jerman, Gereja Katolik dan Gereja Protestan telah menandatangani kesepakatan mengenai pokok ajaran yang paling dipertikaikan dan telah menjadi pangkal penyebab perpecahan gereja sejak 1517. Pokok ajaran itu adalah tentang pembenaran, atau lengkapnya, pembenaran oleh iman. Itu berarti bahwa "damai ajaran" atau "damai teologi" di kalangan gereja-gereja yang bertikai karenanya, bukan sesuatu yang mustahil terjadi. Kita bersyukur bahwa Roh Kudus terus-menerus bekerja mendamaikan gereja-gereja Kristus yang bertikai.

\section{Bolehkah Gereja-Gereja Kristen tetap Terpisah?}

Inilah sebuah pertanyaan yang diajukan oleh seorang teolog Katolik, Georg Kirchberger, dalam artikel yang ditulisnya dengan judul yang sama. ${ }^{35}$ Dalam artikelnya itu ia berkata bahwa bertolak

\footnotetext{
${ }^{31}$ Andar Ismail, Selamat Berkiprah (Jakarta: BPK Gunung Mulia, 2001), 121.

${ }^{32}$ End, 95 Dalil Martin Luther, 23.

${ }^{33}$ lbid.

${ }^{34}$ Ismail, Selamat Membarui, 127.

${ }^{35}$ Georg Kirchberger, "Bolehkah Gereja-Gereja Kristen Tetap Terpisah?"," Jurnal Ledalero 15, no. 2 (2016):
} 190-215. 
dari penegasan Konsili Vatikan II bahwa Gereja itu merupakan satu kawanan, tidak ada gerejagereja Allah dalam bentuk jamak, Allah hanya mendirikan satu Gereja melalui perutusan Putera dan Roh-Nya. Semua orang Kristen dari semua gereja Kristen menjadi anggota pada satu tubuh Kristus. Inilah suatu ikatan yang sangat kuat dan pada dasarnya mesti dianggap lebih utama dari pelbagai perbedaan yang mengurangi persekutuan itu. Oleh karena itu, mesti ditanya, apa yang bisa dianggap sebagai perbedaan yang cukup besar untuk memberikan hak, untuk tetap menyatakan diri sebagai gereja terpisah? ${ }^{36}$ Pertanyaan ini coba dijawab dengan menunjuk kepada satu inisiatif teologis penting yang telah terjadi pada 38 tahun yang lalu yakni tahun 1983. Dua teolog besar Katolik, Karl Rahner dan Heinrich Fries, menerbitkan sebuah buku kecil yang dalamnya mereka menyatakan dalam delapan tesis bahwa seturut pandangan mereka, kesatuan di antara Gereja-gereja Kristen sudah bisa menjadi kenyataan. ${ }^{37}$

Kita mencatat bahwa sejarah membuktikan perwujudan harapan mereka pada tanggal 31 Oktober 1999, 16 tahun kemudian, sebagaimana telah dijelaskan di atas tatkala Gereja Katolik dan Protestan dapat menandatangani JDDJ. Oleh karena itu, sekali lagi, bukan mustahil bila gereja-gereja yang berbeda dan bertikai dapat datang pada kesepahaman dan perdamaian. Jalanjalan kearah terbentuknya Gereja Esa sudah mulai terbuka. Jalan tersebut mungkin belum menjadi jalan lebar. Namun "jalan-jalan sempit" atau "jalan-jalan perintis" sudah tersedia. Kita dapat menyebut beberapa hal berkaitan dengan hal itu:

- $\quad$ Luther dan Calvin sebenarnya tidak berkehendak membentuk gereja sendiri. Maksud utama mereka adalah meluruskan praktik yang telah menyimpang dari ajaran yang berlaku saat itu. Bila otoritas Gereja di Roma waktu itu menerima protes Luther, maka tidak ada gereja terpisah yang namanya Gereja Katolik dan Gereja Protestan.

- Gereja Anglican di Inggris mempunyai ajaran yang mirip Protestan (Calvinis). Namun organisasi gerejanya mirip Katolik (Papal/Episkopal).38

- $\quad$ Di Indonesia, KWI dan PGI sudah lama bekerja sama dalam merumuskan pesan-pesan keagamaan pada Masaraya Natal dan atau Paskah.

- $\quad$ Badan Penerbit Kristen BPK Gunung Mulia dan Kanisius, Penerbit Katolik sudah cukup lama bekerja sama dalam penerbitan buku-buku teologi.

- Cukup lama telah terjadi pertukaran dosen/pengajar antara sekolah teologi dan seminari katolik atau Sekolah Tinggi Filsafat.

\section{Tanggal 31 Oktober Harus Dirayakan dan Disyukuri Setiap Tahun secara Bersama}

Andar Ismail mengatakan,

Sungguh bersejarah bahwa 500 tahun Reformasi Gereja bisa dirayakan bersama oleh Gereja Katolik dan Protestan. Orang Katolik dan Protestan sama-sama dikelilingi oleh "dunia membenci" dan "dunia tidak mengenal engkau" (Yoh.21). Oleh sebab itu, orang Katolik dan Protestan sedang didoakan oleh Kristus "supaya mereka semua menjadi satu". Kebersatuan Katolik dan Protestan itu dimaksudkan oleh Kristus "supaya dunia percaya". Bahkan bukan sekedar "supaya dunia percaya", melainkan "agar dunia tahu... bahwa Engkau mengasihi mereka. Maksudnya bahwa "Allah begitu mengasihi dunia ini. ${ }^{39}$

Maka sekarang, tanggal 31 Oktober bukan saja merupakan hari bersejarah bagi Gereja Protestan. Tanggal itu telah menjadi moment bersejarah bagi kedua gereja. Tanggal 31 Oktober sekarang adalah milik bersama. Oleh karena itu, pada setiap tanggal 31 Oktober, Gereja Protestan dan Katolik harus melakukan perayaan bersama dengan meriah.

\footnotetext{
${ }^{36}$ Ibid., 190-191.

${ }^{37}$ Heinrich Fries and Karl Rahner, Einigung Der Kirchen (Freiburg: Heider, 1985).

${ }^{38}$ Aritonang, Berbagai Aliran Di Dalam Dan Di Sekitar Gereja, 96-124.

${ }^{39}$ Ismail, Selamat Membarui, 129.
} 


\section{Ad Fontes: Kembali ke Sumber-sumber Asli}

Reformasi yang dilakukan Martin Luther berhasil menggiring gereja yang direformasikan itu kembali kepada sumber-sumber ajaran yang benar yaitu Alkitab dan ajaran para Patristik, khususnya Augustinus. Dengan kata lain, permasalahan dalam institusi gereja menyangkut ajaran dan praktik bergereja yang dipandang keliru waktu itu, bisa dipecahkan dengan semboyan "ad fontes", kembali ke sumber-sumber asli. Protestan dan Katolik bisa menghasilkan "Kesepakatan Augsburg" karena kembali ke Alkitab. Bukankah ini bisa menjadi pelajaran berharga bagi GerejaGereja di Indonesia dalam melihat persoalan bermasyarakat dan berbangsa dewasa ini? Dewasa ini integritas dan keutuhan bangsa kita hendak dicabik-cabik. Tingkat intoleransi makin tinggi, kesadaran pluralitas makin rendah, sikap menghargai sesama yang berbeda dengan kita mulai menipis, kehendak mengganti bentuk Negara bermunculan dari kelompok tertentu. Dalam situasi ini, kita bisa belajar dari reformasi abad ke-16. Bila reformasi abad ke-16 berhasil membawa transformasi masyarakat karena kembali ke sumber-sumber asli yang menjadi dasar, maka transformasi masyarakat Indonesia juga bisa terjadi dewasa ini, bila ada kehendak dan niat baik seluruh komponen masyarakat untuk kembali kepada sumber-sumber asli kehidupan berbangsa dan bernegara yakni Pancasila, Undang-Undang Dasar 1945, Bhineka Tunggal Ika dan Negara Kesatuan Republik Indonesia (NKRI). Persoalan-persoalan bermasyarakat dan berbangsa bisa diselesaikan bila semua pihak menundukkan diri kepada keempat pilar kehidupan berbangsa dan bernegara serta membiarkannya berbicara mengilhami cara berpikirnya.

\section{Jangan mengabaikan Alkitab dan tradisi}

Pengembangan teologi kontekstual dewasa ini disadari telah membawa efek lain dalam bersikap terhadap Alkitab dan tradisi. Dalam mengembangkan teologi kontekstual, orang cenderung mengutamakan konteks masa kini belaka sebagai yang satu-satunya menentukan. Kecenderungan ini, memang pada satu pihak, menyebabkan kita kaya dengan pengenalan akan konteks. Tetapi pada pihak lain, dapat menyebabkan "kemiskinan" pada ranah Alkitab dan tradisi. ${ }^{40}$ Orang bisa cenderung mengabaikan Alkitab dan tradisi dalam berteologi kontekstual. Dalam kaitan itu, Gereja-gereja Reformatoris di Indonesia hendaknya sadar dan tetap konsisten memberikan posisi penting terhadap Alkitab dan tradisi dan berteologi. Dapat dikatakan bahwa bila Luther tidak kembali kepada Alkitab, dan selanjutnya bila ia tidak kembali pula kepada tradisi (dalam hal ini Bapa Gereja khususnya Augustinus), maka tidak akan ada Protestantisme di dunia ini. Protestantisme bisa hadir dan eksis karena Alkitab dan tradisi. Karena itu, Gereja-gereja Reformatoris perlu menjaga agar dalam mengembangkan teologi kontekstual, Alkitab, tradisi dan konteks harus selalu diperhatikan dan berjalan beriringan.

\section{KESIMPULAN}

Gereja-gereja Reformatoris di Indonesia perlu kiranya terus-menerus diilhami oleh semboyan ecclesia reformata semper reformanda dalam mengembangkan teologi, ajaran, dan praktiknya. Gereja-gereja Reformatoris tidak boleh menjadi gereja yang merasa diri telah mapan dan paling benar. Proses mereformasi diri ke arah kemapanan, dan menjadi gereja yang benar, tidak boleh berhenti. la harus menjadi gereja yang terbuka pada perkembangan zaman, terbuka kepada Gereja Katolik, bahkan kepada agama-agama lain. Pertanyaan yang mungkin perlu terus direnungkan setiap kali tanggal 31 Oktober tiba adalah, dapatkah Gereja Protestan dan Katolik bersatu? Kedua-duanya memiliki dasar yang sama, kendati dalam hal ajaran masih terdapat perbedaan tajam pada beberapa pokok. Meskipun demikian, perbedaan-perbedaan yang tajam itu mungkin bisa diperkecil bila dialog dan kerjasama makin diintensifkan dari waktu ke waktu. Pertanyaan yang menantang kalangan Protestan adalah, seandainya "Gereja Esa" dapat tercipta antara Gere-

\footnotetext{
${ }^{40}$ Joas Adiprasetya, "Arah Baru Eklesiologi Masa Kini," in Menggereja Secara Baru Di Indonesia, ed. Yusak Soleman (Jakarta: PERSETIA, 2015), 39.
} 
ja Katolik dan Protestan, maka apakah harus terus-menerus ada alasan bagi kalangan Protestan yang beraneka ragam alirannya itu untuk tetap terpisah satu sama lain? Reformasi Gereja bagi kita haruslah berarti pula Keesaan Gereja.

\section{REFERENSI}

Adiprasetya, Joas. "Arah Baru Eklesiologi Masa Kini." In Menggereja Secara Baru Di Indonesia, edited by Yusak Soleman. Jakarta: PERSETIA, 2015.

Aritonang, Jan S. Berbagai Aliran Di Dalam Dan Di Sekitar Gereja. Jakarta: BPK Gunung Mulia, 2016.

Aritonang, Jan Sihar. Garis Besar Sejarah Reformasi. Bandung: Jurnal Info Media, 2007.

Drewes, B.F., and Julianus Mojau. Apa Itu Teologi? Jakarta: BPK Gunung Mulia, 2003.

End, Th. van den. 95 Dalil Martin Luther. Jakarta: BPK Gunung Mulia, 2017.

End, Th. Van den. Harta Dalam Bejana. Jakarta: BPK Gunung Mulia, 1982.

Fries, Heinrich, and Karl Rahner. Einigung Der Kirchen. Freiburg: Heider, 1985.

Ismail, Andar. Selamat Berkiprah. Jakarta: BPK Gunung Mulia, 2001.

- Selamat Membarui. Jakarta: BPK Gunung Mulia, 2017.

Jonge, Christiaan de. Menuju Keesaan Gereja. Jakarta: BPK Gunung Mulia, 1990.

Kirchberger, Georg. "Bolehkah Gereja-Gereja Kristen Tetap Terpisah?"." Jurnal Ledalero 15, no. 2 (2016): 190-215.

Krisyanto, Eddy, ed. Musa Jerman. Jakarta: BPK Gunung Mulia, 2017.

Lane, Tony. Runtul Pijar. Jakarta: BPK Gunung Mulia, 1990.

Norwich, John Juliua. The Popes A History. London: Chatto \& Windus, 2011.

PGI. Dokumen Keesaan Gereja 2019-2024. Jakarta: BPK Gunung Mulia, 2020.

Ramli SN Harahap. Deklarasi Bersama Tentang Ajaran Pembenaran Oleh Iman. Yogyakarta: Kanisius, 2015.

Tanner, Norman P. Konsili-Konsili Gereja Sebuah Sejarah Singkat. Yogyakarta: Kanisius, 2003. 